\title{
The Importance of Conjugation with Glutathione for Sulfo- bromophthalein Sodium (BSP) Transfer from Blood to Bile*
}

\author{
Burton Combes $\dagger$ \\ (From the Department of Internal Medicine, Liver-Gastroenterology Unit, University of \\ Texas Southwestern Medical School, Dallas, Texas)
}

After intravenous administration, BSP is removed from blood, predominantly by the liver, and subsequently is excreted into the bile. It is now generally agreed that a considerable amount of BSP is conjugated with glutathione within the liver cell (1-3), a process catalyzed by a supernatant enzyme (4). BSP-cysteinyl glycine and $\mathrm{BSP}$-cysteine are also formed $(1,2,4)$, probably by cleavage of amino acids from the tripeptide glutathione moiety, which is conjugated to BSP. BSP conjugates and free BSP are then excreted into bile. In man $(5-7)$, the rat $(6,8,9)$, and $\operatorname{dog}(2,5)$, BSP conjugates account for most of the BSP appearing in bile, approximately 75 to $85 \%$ in some studies. The preponderance of conjugated BSP in bile suggests that metabolized BSP is preferentially excreted. However, the observation that free BSP appears in bile leaves uncertain whether conjugation is important for or merely incidental to the hepatic uptake and biliary excretion of BSP.

An assessment of the importance of conjugation on the movement of BSP from blood to bile was undertaken in the present studies conducted in rats. The concentrations of the components of

* Submitted for publication January 22, 1965 ; accepted March 18, 1965.

These studies were supported by research grant HE-03439 from the National Institutes of Health, U. S. Public Health Service. Part of this work was presented at the Fifty-fourth Annual Meeting of the American Society for Clinical Investigation, Atlantic City, N. J., April 1962, and appears in abstract form in J. clin. Invest. 1962, 41, 1351, and in Clin. Res. 1962, 10, 54.

+ Part of this work was carried out during the tenure of an Established Investigatorship of the American Heart Association. Recipient of a Research Career Development Award. Address requests for reprints to Dr. Burton Combes, Dept. of Internal Medicine, University of Texas Southwestern Medical School, Dallas, Texas 75235. the BSP-glutathione conjugating system in liver, namely, conjugating enzyme and glutathione, were altered by dietary means. The effect of these changes in the conjugating system on hepatic uptake and biliary excretion of BSP was examined in detail. Results of these studies indicate that conjugation of $\mathrm{BSP}$ with glutathione exerts an important effect on the extent of transfer of BSP from blood to bile. Although conjugation does not appear to affect hepatic uptake of BSP directly, it does affect the maximal rate at which $\mathrm{BSP}$ is transported from liver cells into bile, conjugated BSP being excreted preferentially into bile.

\section{Methods}

1) Effect of diet on BSP conjugating enzyme activity and glutathione and protein nitrogen content of rat liver. Previous studies of Leaf and Neuberger (10), and Edwards and Westerfield (11), demonstrated that liver glutathione levels fall rapidly when rats are fed a proteinfree diet. Incorporation of cystine into the protein-free diet prevented the fall in glutathione, however. In the present studies, adult male Sprague-Dawley rats were placed on either a protein-free $\operatorname{diet}^{1}$ or on a proteinfree diet supplemented with $1 \%$ cystine for 1 to 21 days. Control rats were fed a stock pellet diet. After various intervals on the experimental diets, groups of rats were sacrificed by decapitation; livers were removed rapidly, weighed, placed in chilled beakers, and portions taken for analysis of tissue components. BSP conjugating enzyme activity was assayed in homogenates of liver by the method described in detail in a previous publication (12). Protein nitrogen was determined by microKjeldahl analysis of samples of liver homogenate digested before and after precipitation of protein with $10 \%$ trichloroacetic acid. Duplicate slices of liver were assayed for glutathione content by the nitroprusside method of Grunert and Phillips (13). It is recognized that the latter method permits measurement of the nonprotein sulfhydryl compounds in liver, and is not specific for

1 These diets, purchased from Nutritional Biochemicals Corp., Cleveland, Ohio, were supplemented with a vitamin fortification mixture. 
glutathione per se. Leaf and Neuberger (10) obtained virtually identical results for liver glutathione content, however, with a nitroprusside method and the more specific manometric method of Woodward (14), when rats were fed diets similar to those employed in the present studies.

2) Measurement of BSP excretion into bile. The common bile ducts of adult male control rats and animals fed the experimental diets were cannulated with fine polyethylene tubing. Varying doses of $\mathrm{BSP}^{2}$ per $100 \mathrm{~g}$ body weight were administered intravenously over a period of approximately 30 seconds, and bile was collected for 45 minutes in tared bottles. Bile volume was considered equivalent to the weight of the bile collected in this period. The concentration of BSP in bile was determined colorimetrically in a Beckman DU spectrophotometer set at $580 \mathrm{~m} \mu$, on appropriately diluted bile specimens to which alkali had been added. The product of BSP concentration and bile volume yields a value for total BSP excretion in bile. Distribution of BSP compounds appearing in bile was determined chromatographically by methods described in detail in previous publications $(6,12)$. The quantity of $\mathrm{BSP}$ excreted as conjugated (chromatographic bands $A, B, C$ ) and free (band D) BSP was calculated as the product of total BSP excreted in bile and the per cent of total BSP appearing in each of the chromatographic bands. For these studies, it was assumed that the molecular extinction coefficients of free and conjugated BSP were identical. BSP concentration in plasma was estimated by the method of Gaebler (15) on blood samples collected by cardiac puncture at 45 minutes after BSP administration. The rats were kept lightly anesthetized with ether during the procedure.

3) Estimation of hepatic uptake of BSP. Ten $\mathrm{mg}$ of BSP per $100 \mathrm{~g}$ body weight was administered intravenously to adult male rats whose common bile ducts had just been ligated, thus preventing significant biliary excretion of BSP. The livers were removed at 5, 15, and 45 minutes after injection and analyzed for BSP content and for the proportion of BSP contained as conjugated and free BSP. Blood samples were obtained from rats sacrificed at 15 and 45 minutes for estimation of plasma BSP concentration. For quantitation of hepatic BSP content, triplicate samples of liver weighing approximately $1 \mathrm{~g}$ each were homogenized for 1 minute with $2 \mathrm{ml}$ of acetone in a motor-driven homogenizer utilizing a Teflon pestle. ${ }^{3}$ The contents of each tube were transferred with the aid of $3 \mathrm{ml}$ of $83.3 \%$ acetone to glass-stoppered conical centrifuge tubes. The contents were thoroughly mixed and the tubes centrifuged for 10 minutes at $4,500 \mathrm{rpm}$. The supernate was removed, and precipitate extracted twice with $3 \mathrm{ml}$ of $83.3 \%$ acetone; the supernates were pooled, and the vol-

2 The BSP used in these studies was the $5 \%$ solution sold commercially by Hynson, Westcott and Dunning, Inc., of Baltimore, Md.

${ }^{3}$ Purchased from Kontes Class Co., Vineland, N. J. ume was recorded. Duplicate $150-\mu 1$ samples of the combined acetone extracts were mixed with $4 \mathrm{ml}$ of 0.1 $\mathrm{N} \mathrm{KOH}$, and the optical density was determined using $0.1 \mathrm{~N} \mathrm{KOH}$ as a blank in a Beckman DU spectrophotometer set at $580 \mathrm{~m} \mu$. BSP extracted per gram of liver wet weight was calculated as follows: OD 580 (unknown)/OD 580 (standard) $\times$ concentration of standard in $\mathrm{mg}$ per $100 \mathrm{ml} \times$ volume of acetone extract in fractions of $100 \mathrm{ml} /$ weight of liver sample in grams. Samples of the combined acetone extracts were applied to Whatman 1 filter paper strips and chromatographed in order to determine the distribution of BSP compounds.

Recovery in the acetone extracts of known amounts of unconjugated BSP and BSP-glutathione added to samples of liver averaged 94.0 and $40.8 \%$, respectively. Recoveries were the same when BSP compounds were added to liver in which bile ducts had been obstructed for up to 45 minutes. Of the free BSP and BSP-glutathione originally applied at the origin in an acetone-water mixture, 90.8 and $100 \%$, respectively, were recovered in eluates of the respective BSP bands after chromatographic development. Corrections were made for the incomplete recoveries in extraction and chromatography to arrive at the values for milligrams of the respective fractions of BSP contained per gram liver weight.

4) Comparison of BSP compounds excreted in bile with those contained in liver. Ten $\mathrm{mg}$ BSP per $100 \mathrm{~g}$ body weight was injected intravenously in adult male rats whose common bile ducts were cannulated with fine polyethylene tubing. Bile flow was not interrupted after cannulation. However, bile was collected for analysis only for several minutes before the liver was removed. Thus, in three groups of animals, bile was collected from 7 to 10 minutes, and the liver removed at 10 minutes; bile collected 25 to 30 minutes, liver removed at 30 minutes; bile collected 40 to 45 minutes, liver removed at $45 \mathrm{~min}$ utes after BSP administration. BSP was extracted from the livers. The acetone extracts were chromatographed, and the distribution of BSP compounds in liver was determined as described above. Bile samples were also chromatographed, and the distribution of BSP compounds excreted in bile was compared to that contained in liver.

\section{Results}

\section{1) Liver composition}

Data are expressed per gram wet weight of liver and per $100 \mathrm{~g}$ body weight since BSP was administered on the basis of per $100-\mathrm{g}$ rat in subsequent experiments.

a) Glutathione content (Table I). Hepatic glutathione levels averaged $1.87 \pm \mathrm{SD} 0.26 \mathrm{mg}$ per $\mathrm{g}$ liver and $7.9 \pm 1.3 \mathrm{mg}$ per $100 \mathrm{~g}$ body weight in control rats. Glutathione content fell rapidly to approximately $20 \%$ of control values (expressed per $100 \mathrm{~g}$ body weight) in animals fed a protein- 


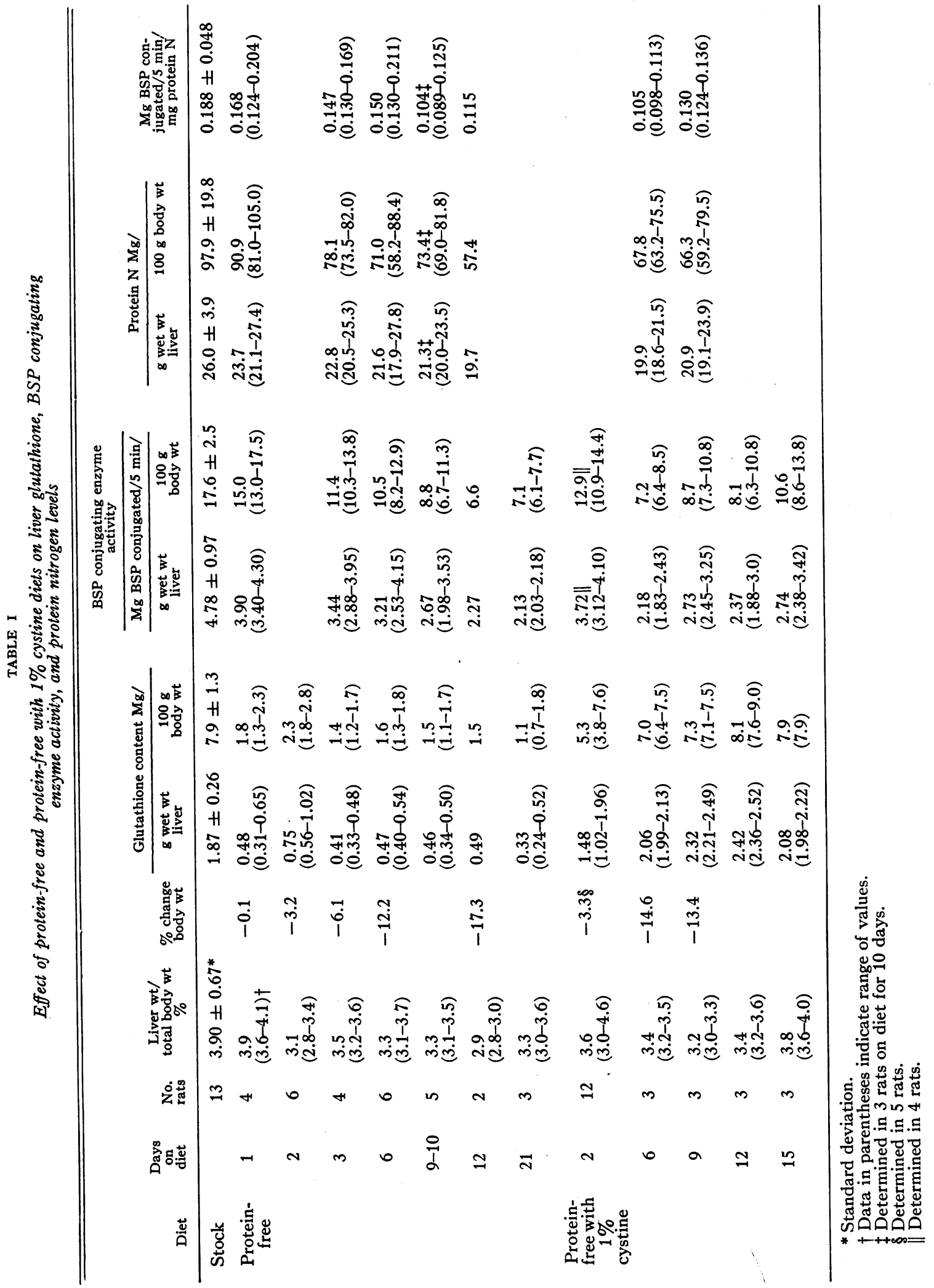


free diet, confirming earlier studies $(10,11)$. The maximal fall was achieved virtually within 24 hours and persisted with little additional change when rats were maintained on the diet for as long as 21 days. In contrast, hepatic glutathione levels decreased to only $67 \%$ of control values after 2 days and returned toward or to control levels after 6 to 15 days in rats fed a protein-free diet supplemented with $1 \%$ cystine.

b) Protein nitrogen content (Table I). Protein nitrogen levels fell progressively in rats fed the protein-free diet for as long as 12 days. The protein nitrogen values decreased approximately to the same extent on days 6,9 , and 12 in rats maintained on the protein-free diet containing $1 \%$ cystine.

c) BSP-glutathione conjugating enzyme activity (Table I). Conjugating enzyme activity decreased relatively rapidly during the first 3 days on the protein-free diet, to $64.8 \%$ of control values. It then fell more slowly reaching levels between 37.5 and $40.4 \%$ of control after 12 and 21 days on the diet. Enzymic activity appeared to fall approximately to the same extent from days 2 to 15 in rats fed the protein-free diet supplemented with $1 \%$ cystine. Conjugating enzyme activity decreased to a greater extent than protein nitrogen content in rats maintained on each of the experimental diets (Table I).

The results of BSP administration are confined in the present report to animals maintained on the experimental diets for 2 days. Data obtained in rats on diets for 12 to 14 days will form the basis of a subsequent communication.

\section{2) BSP excretion into bile}

Varying doses of BSP per $100 \mathrm{~g}$ body weight were administered intravenously to control rats and animals on the experimental diets. The quantity of BSP collected in bile in 45 minutes is expressed per $100 \mathrm{~g}$ body weight.

a) Control diet (Table II). Increasing amounts of BSP were excreted into bile as the quantity injected increased (Figure 1). Maximal excretion of $4.12 \mathrm{mg}$ was noted when $10 \mathrm{mg}$ BSP per $100 \mathrm{~g}$ body weight was administered. Fractionation of BSP compounds appearing in bile indicated that band $\mathrm{A}$, which contains BSP-glutathione, accounted for most of the BSP excreted at all dos- age levels. Maximal excretion of the BSP in band A occurred at the 10-mg dose. Bands B and $\mathrm{C}$, which also contain conjugated BSP compounds, accounted for a much smaller fraction of the BSP excreted. The quantity of BSP excreted in these latter two bands reached maximal levels at the 3-mg dose and changed little with further increased dosage. Increasing amounts of free BSP, band $\mathrm{D}$, were excreted with each increment in dose administered. However, the maximal quantity of free BSP excreted; $0.93 \mathrm{mg}$, represented only $26 \%$ of the BSP collected in bile at the $15-$ mg dose. Conjugated BSP (bands A, B, and C) accounted for 73 to $84 \%$ of the total BSP excreted into bile over the range of doses administered in these studies. The average BSP concentration in bile for the 45-minute collection period rose progressively, reached a maximal level of $1,480 \mathrm{mg}$ per $100 \mathrm{ml}$ at the $7.5-\mathrm{mg}$ dose, and remained approximately at this concentration despite a further increase in administered dose to $15 \mathrm{mg}$ per $100 \mathrm{~g}$ body weight (Table II).

b) Protein-free diet for 2 days. After 2 days on the protein-free diet, liver composition, expressed per $100 \mathrm{~g}$ body weight, changed as follows: glutathione was $29.1 \%$, BSP conjugating enzyme activity, approximately $75 \%$, and protein content, approximately $86 \%$ of control levels (Table I). Values for the latter two components were taken as the mean of data obtained on days 1 and 3. Body weight decreased $3.2 \%$ on the average. When BSP was administered to these rats, less BSP was excreted into bile than in control animals at doses of BSP of $7.5 \mathrm{mg}$ per $100 \mathrm{~g}$ (Table II, Figure 2) and higher. This was the consequence of diminished biliary concentration of BSP, since bile volume was comparable to that in control animals. Less conjugated BSP was excreted at each dose level. By contrast, more free BSP appeared in bile. However, the increment in free BSP excretion was insufficient to keep total BSP excretion of the rats on a proteinfree diet at control levels with BSP doses of 7.5 $\mathrm{mg}$ per $100 \mathrm{~g}$ or greater. Plasma levels of BSP were higher than control in these animals with diminished BSP excretion into bile.

c) Protein-free diet supplemented with $1 \%$ cystine for 2 days. Liver glutathione content of $5.3 \mathrm{mg}$ per $100 \mathrm{~g}$ body weight after 2 days on this 


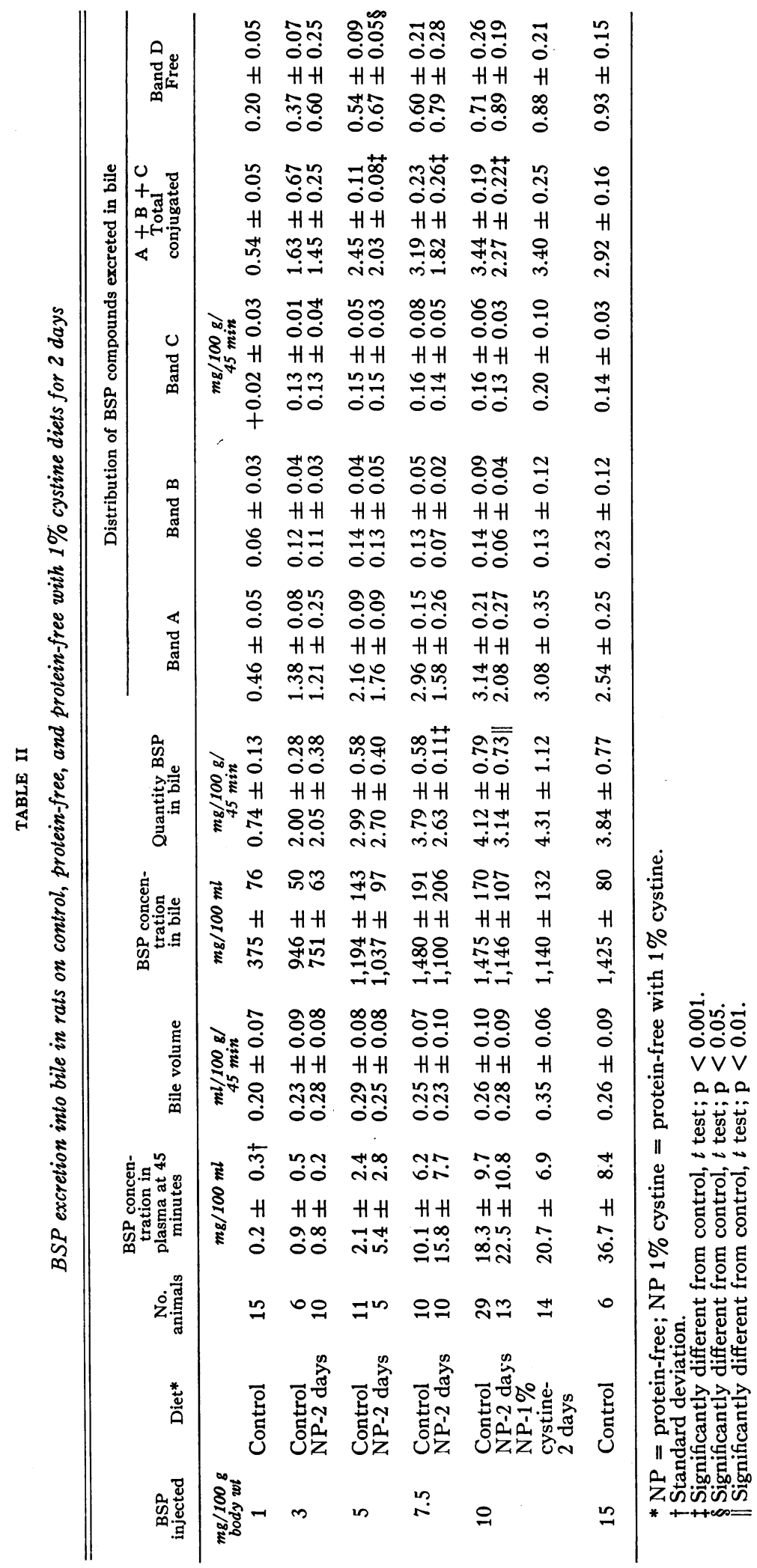




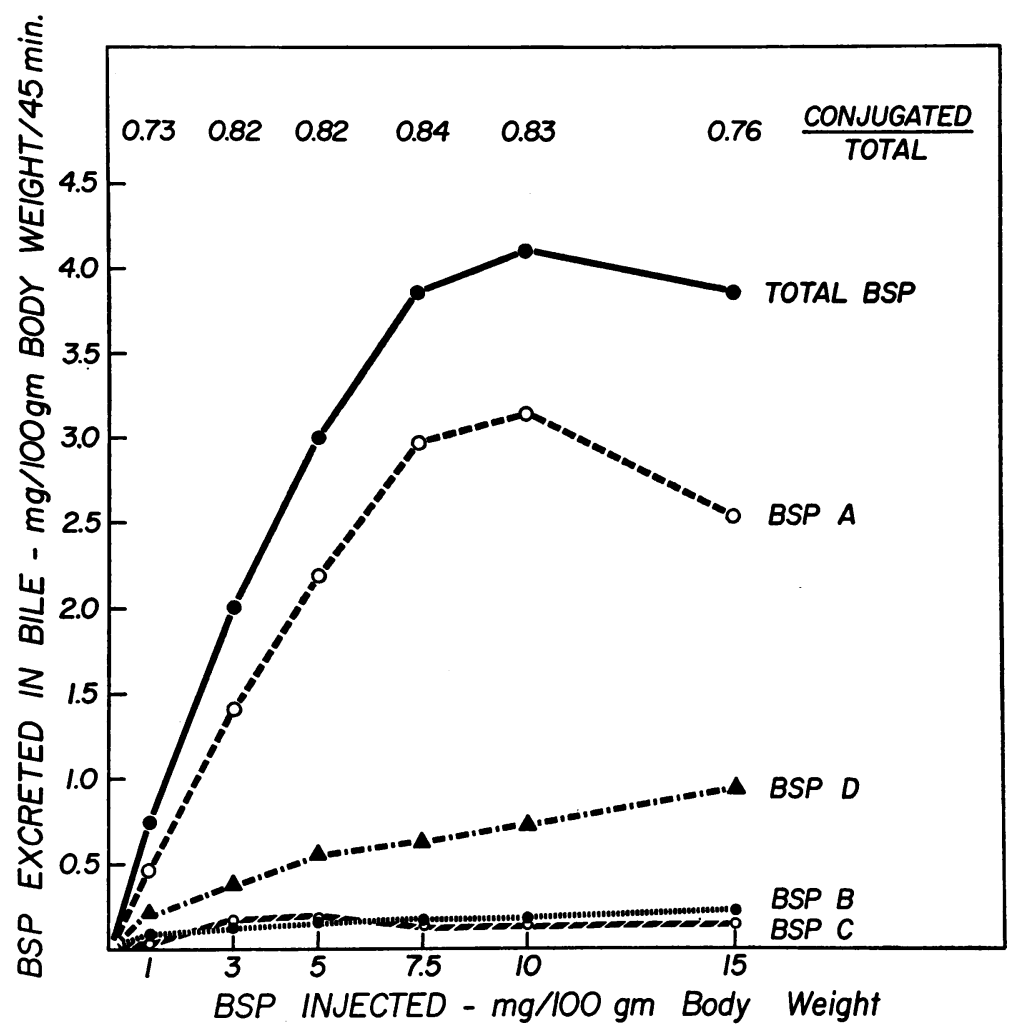

Fig. 1. TOTal QUANTITY OF SUlFobromophthaleIN SODIUM (BSP) AND DISTRIBUTION OF BSP COMPOUNDS EXCRETED INTO BILE IN 45 MINUTES IN RATS RECEIVING VARYING DOSES OF BSP INTRAVENOUSLY.

diet was $67 \%$ of control values (Table I). BSP-glutathione conjugating enzyme activity and body weight fell approximately to the same extent as in rats fed the protein-free diet. Only the $10-\mathrm{mg}$ dose per $100 \mathrm{~g}$ body weight was administered to these animals. Excretion into bile of conjugated and free BSP was comparable to that of control animals (Table II, Figure 3).

\section{3) Hepatic uptake of BSP (Table III)}

Unconjugated BSP accounted for 64.2 and $74.9 \%$ of the dye in the livers of the rats on control and protein-free diets for 2 days, respectively, 5 minutes after intravenous injection. By 45 minutes, although the proportion of conjugated BSP in the livers of these animals had at least doubled (35.8 to $70.2 \%$ in controls, 25.1 to $66.9 \%$ in protein-free), the total quantity of BSP contained per gram of liver had increased by only $30 \%$ on the average $(0.84$ at 5 minutes to $1.10 \mathrm{mg}$ per $\mathrm{g}$ at 45 minutes in controls, 0.90 at 5 minutes to 1.16 $\mathrm{mg}$ per $\mathrm{g}$ at 45 minutes in protein-free). A greater fraction of the hepatic BSP was conjugated in the control than in the protein-free rats at 5 and 15 minutes after injection. Distribution of BSP compounds in the livers of these animals was similar at 45 minutes, however. The milligrams of BSP contained per gram of liver at each interval was almost the same in both groups of animals ( 5 minutes -0.84 controls, 0.90 proteinfree; 15 minutes -0.98 controls, 0.90 protein-free; 45 minutes-1.10 controls, 1.16 protein-free). Total hepatic BSP per 100-g rat was somewhat higher in the control rats, however, since the proportion of body weight accounted for by liver fell an average of $13.4 \%$ in the rats on the proteinfree diet.

\section{4) Comparison of BSP compounds excreted in bile with those contained in liver (Table IV)}

Proportionately more conjugated and less free BSP were present in bile than in liver in both 

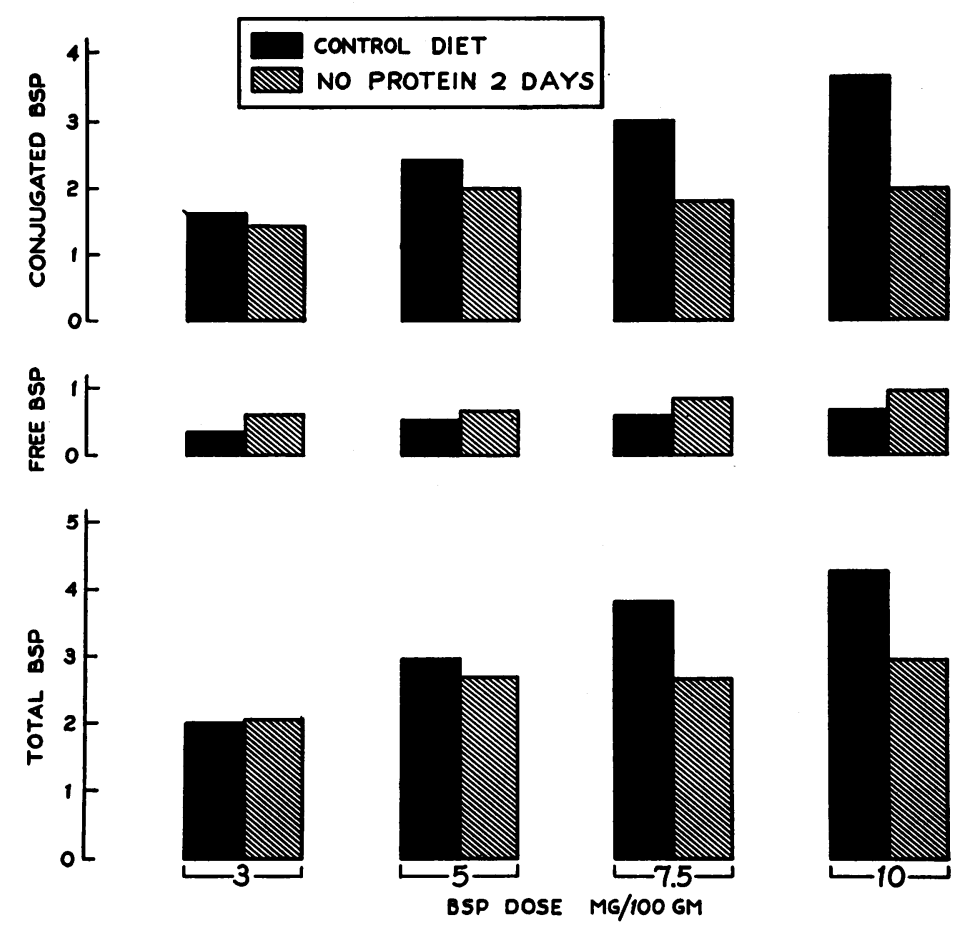

Fig. 2. EFFECT OF PROTEIN-FREE DIET FOR 2 DAYS ON BSP EXCRETION INTO BILE IN RATS RECEIVING VARYING DOSES OF BSP INTRAVENOUSLY. Units for the ordinate are mg BSP per $100 \mathrm{~g}$ body weight per $45 \mathrm{~min}$ utes. Total BSP excreted in bile was significantly lower in the rats on the protein-free diet at doses of administered BSP of $7.5 \mathrm{mg}$ per $100 \mathrm{~g}$ body weight and higher. This was the consequence of decreased excretion of conjugated BSP.

the control and protein-free rats at each time in- BSP contained in liver and in bile was conjugated terval after intravenous administration of dye. in the control than in the protein-free animals at Furthermore, a relatively greater fraction of the any sampling period.

TABLE III

Hepatic uptake of BSP in rats with ligated common bile ducts

\begin{tabular}{|c|c|c|c|c|c|c|}
\hline \multirow[b]{2}{*}{ Diet } & \multicolumn{2}{|c|}{$5 \min *$} & \multicolumn{2}{|c|}{15 min* } & \multicolumn{2}{|c|}{45 min* } \\
\hline & Control & $\begin{array}{l}\text { Protein-free } \\
2 \text { days }\end{array}$ & Control & $\begin{array}{c}\text { Protein-free } \\
2 \text { days }\end{array}$ & Control & $\begin{array}{l}\text { Protein-free } \\
2 \text { days }\end{array}$ \\
\hline Number of rats & 2 & 2 & 3 & 3 & 3 & 3 \\
\hline $\begin{array}{c}\text { Plasma BSP, } \\
m g / 100 m l\end{array}$ & & & 61.3 & 55.9 & 44.6 & 50.6 \\
\hline$\frac{\text { Liver weight }}{\text { Body weight }}, \%$ & 3.77 & 3.17 & 3.57 & 3.29 & 3.59 & 3.00 \\
\hline $\begin{array}{l}\mathrm{Mg} \mathrm{BSP} / \mathrm{g} \text { liver } \\
\% \text { conjugated } \\
\% \text { free }\end{array}$ & $\begin{array}{l}0.84 \\
35.8 \\
64.2\end{array}$ & $\begin{array}{l}0.90 \\
25.1 \\
74.9\end{array}$ & $\begin{array}{l}0.98 \\
46.9 \\
53.1\end{array}$ & $\begin{array}{l}0.90 \\
33.4 \\
66.6\end{array}$ & $\begin{array}{l}1.10 \\
70.2 \\
29.8\end{array}$ & $\begin{array}{l}1.16 \\
66.9 \\
33.1\end{array}$ \\
\hline $\begin{array}{l}\text { Mg liver BSP/ } \\
100-g \text { rat }\end{array}$ & 3.17 & 2.86 & 3.52 & 2.92 & 3.91 & 3.45 \\
\hline
\end{tabular}

* Minutes after injection. 

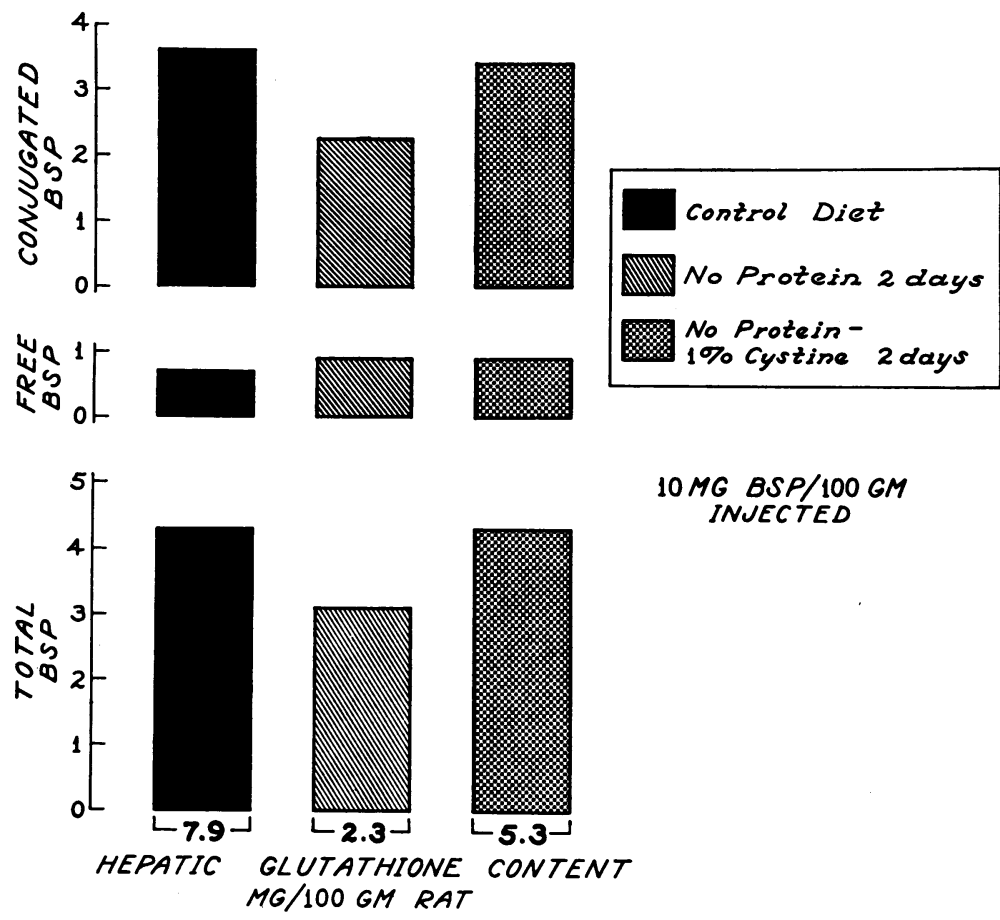

Fig. 3. COMPaRison OF BSP EXCRETION INTO BILE IN RATS ON CONTROL, PROTEIN-FREE, AND PROTEIN-FREE SUPPLEMENTED WITH $1 \%$ CYSTINE DIETS WHEN 10 MG BSP PER 100 G BODY WEIGHT WAS ADMINISTERED INTRAVENouSLy. Units for the ordinate are $\mathrm{mg}$ BSP per $100 \mathrm{~g}$ body weight per 45 minutes. The marked fall in hepatic glutathione levels induced by a protein-free diet was accompanied by decreased BSP excretion into bile due to a fall in excretion of conjugated BSP. By contrast, when hepatic glutathione levels were bolstered by feeding a protein-free diet supplemented with $1 \%$ cystine, total BSP excretion into bile returned to control values, primarily due to excretion of conjugated BSP at control levels.

\section{Discussion}

The present studies demonstrate that conjugation of BSP with glutathione exerts an important effect on the extent of transfer of BSP from blood to bile. First, conjugated BSP compounds accounted for 73 to $84 \%$ of the dye excreted into bile over a wide range of administered doses. Second, at intravenous doses of $7.5 \mathrm{mg}$ per $100 \mathrm{~g}$ body weight and higher, BSP excretion into bile fell due to diminished excretion of conjugated BSP when the components of the hepatic BSPglutathione conjugating system, namely, glutathione, the substrate for conjugation, and the enzyme that catalyzes conjugation, were decreased by feeding a protein-free diet for 2 days. Third, biliary excretion of conjugated, and thus total $\mathrm{BSP}$, was restored to maximal control levels when hepatic glutathione levels were bolstered by feed- ing a protein-free diet supplemented with $1 \%$ cystine for 2 days, suggesting that conjugation of BSP with glutathione is an important determinant of the maximal rate at which BSP is transferred from blood to bile. Since conjugating enzyme ac-

TABLE IV

Relative distribution of BSP compounds excreted into bile with those contained in liver

\begin{tabular}{|c|c|c|c|c|c|}
\hline \multirow[b]{2}{*}{ Time } & & \multicolumn{2}{|c|}{ Control diet } & \multicolumn{2}{|c|}{$\begin{array}{l}\text { Protein-free } \\
\text { diet, } 2 \text { days }\end{array}$} \\
\hline & & $\begin{array}{l}\% \text { con- } \\
\text { jugated }\end{array}$ & $\%$ free & $\begin{array}{l}\% \text { con- } \\
\text { jugated }\end{array}$ & $\%$ free \\
\hline \multicolumn{6}{|l|}{$\min$} \\
\hline $7-10$ & Bile & 77.9 & 22.1 & 70.5 & 29.5 \\
\hline 10 & Liver & 44.9 & 55.1 & 29.8 & 70.2 \\
\hline $25-30$ & Bile & 86.2 & 13.8 & 66.6 & 33.4 \\
\hline 30 & Liver & 66.4 & 33.6 & 35.3 & 64.7 \\
\hline $40-45$ & Bile & 88.1 & 11.9 & 74.4 & 25.6 \\
\hline 45 & Liver & 68.9 & 31.1 & 44.0 & 56.0 \\
\hline
\end{tabular}


tivity was still decreased to the same extent as in animals on the protein-free diet, glutathione appears to be the limiting factor in conjugation in these short term experiments.

The current studies also reveal that conjugation has little direct effect on hepatic uptake of BSP. In confirmation of Philp, Grodsky, and Carbone (9), conjugation was shown to be unnecessary for BSP uptake to occur. Furthermore, the present studies demonstrate that the quantity of BSP contained in the liver is independent of the degree of conjugation. It seems reasonable to conclude, therefore, that conjugation affects the movement of BSP from blood to bile by increasing the rate at which BSP is delivered from within the liver cells into bile. Additional evidence that conjugated BSP is excreted more rapidly into bile is provided by the studies of Philp, Grodsky, and Carbone (9) in rats and by those of Schenker, Goldstein, and Combes (16) in fetal and adult guinea pigs. This conclusion is further supported by the present observation that proportionately more conjugated and less free BSP was present in bile than in liver from which this BSP had just been secreted. Implicit in this observation is that a greater concentration gradient between liver cells and bile can be generated for conjugated than for unconjugated BSP. Impaired intrahepatic conjugation of BSP would be expected, therefore, to result in a decreased rate of delivery of the dye into bile and a decreased biliary concentration of BSP for any given bile volume.

One can only speculate as to the possible reasons for the greater rate of delivery of conjugated BSP into bile. Bradley (17) has demonstrated that conjugated BSP is less readily bound to bovine serum albumin than is free BSP. Studies in our own laboratory (18) have also shown that conjugated BSP is less readily bound by the proteins of the soluble supernatant fraction of rat liver. The supernatant fraction of liver in the rat represents the major storage compartment of the liver cell for BSP (18) and is the site in which most of the hepatic glutathione (11) and virtually all of the BSP-glutathione conjugating enzyme activity (4) is contained. Conversion of unconjugated BSP to BSP-glutathione within the cell might render the dye less tightly bound to intracellular protein and thus permit greater acces- sibility of conjugated than free BSP to the transport mechanism (s) concerned with delivery of dye into bile. Within this framework, there would be a proportionately higher concentration of unbound conjugated than free dye for any given total concentration of the respective BSP compounds within the liver cell. The apparent larger concentration gradient between liver cell and bile for conjugated BSP, based on total intrahepatic conjugated BSP content, may only reflect, therefore, the relatively higher unbound concentration of conjugated dye and not involve a transport mechanism(s) of different capacity for the respective BSP compounds. Alternatively, there may exist a transport system at the canalicular level for which conjugated BSP has greater affinity than free BSP, or there may be several transport systems for the individual BSP compounds, each of different capacity. An additional consideration concerns the relatively greater lipid solubility of unconjugated than conjugated BSP, even though both compounds are readily water soluble. It is conceivable that BSP compounds are excreted into bile in proportion to their intracellular concentrations, but that free BSP diffuses back across membranes of hepatic or bile ductular cells to a greater extent, resulting in relatively higher concentration in bile of conjugated BSP. Unfortunately, there is no direct evidence available yet to test this possibility.

Assessments of BSP removal mechanisms have been of considerable value in characterizing the hepatic alterations found in some types of hepatic disease and induced by a number of drugs. Such appraisals have been greatly facilitated by the prolonged BSP infusion method of Wheeler, Meltzer, and Bradley (19), which provides quantitative estimates both of uptake of BSP into the hepatic storage compartment and of the maximal rate of BSP excretion into bile, or BSP Tm. The results of the present studies bear significantly, in at least two important ways, on data obtained with the Wheeler method. First, they indicate that impaired BSP conjugation may be expected to result in a decrease in BSP Tm, but will probably not affect values for BSP uptake into the hepatic storage compartment. The adequacy of conjugation must be examined, therefore, when a decreased BSP $\mathrm{Tm}$ is found, since such a finding may be the consequence of impairment of either 
conjugation, or of the transport mechanism(s) concerned with movement of BSP from within liver cells into bile, or both. Second, nutritional disturbances that interfere with BSP conjugation may also be expected to affect values for BSP Tm. Evidence for this has been obtained recently in our laboratory in studies conducted in dogs, in which feeding a protein-free diet for 1 to 2 weeks resulted in a selective decrease in BSP $\operatorname{Tm}(20)$.

Finally, the present data indicate that the maximal rate of BSP excretion into bile, or BSP Tm, per unit of body weight, is much higher in the male rat than in other species for which such information is available, namely, in the dog and man. With allowance for an appearance time into collected bile of approximately 2 to 4 minutes after intravenous administration, BSP $\mathrm{Tm}$ was approximately $0.1 \mathrm{mg}$ per $100 \mathrm{~g}$ rat per minute. This is approximately 5 times greater per unit body weight than the average value of $1.9 \mathrm{mg}$ per minute per $10 \mathrm{~kg}$ in the $\mathrm{dog}$, and 7 to 8 times greater than the value of $8.6 \mathrm{mg}$ per minute in man with an average weight of $65 \mathrm{~kg}$ (19). Part of this species difference can be accounted for by the relatively larger size of the liver per unit body weight in the rat (21). This cannot be the sole explanation, however, for the proportion of body weight accounted for by liver in the rat is only 1.5 to 2 times greater than this value in the dog and man, respectively (21). Whether the species differences in maximal excretory rates for BSP reflect different capacities for BSP conjugation, or for delivery of BSP compounds from liver cells into bile, must await further investigation.

\section{Summary}

The components of the hepatic BSP-glutathione conjugating system were altered by feeding rats a protein-free diet or a protein-free diet supplemented with $1 \%$ cystine. After 2 days, liver glutathione, the substrate for BSP conjugation, fell approximately 80 and $33 \%$ on the respective diets. Activity of the enzyme that catalyzes BSPglutathione conjugation decreased $25 \%$, approximately to the same extent in rats maintained on the two diets. After intravenous administration of dye, excretion of BSP into bile was decreased due to diminished excretion of conjugated BSP in the rats fed a protein-free diet for 2 days. Biliary excretion of conjugated, and thus total BSP, was restored to maximal control levels when hepatic glutathione levels were bolstered by feeding the protein-free diet supplemented with $1 \%$ cystine. The data indicate that intrahepatic conjugation of BSP with glutathione exerts an important effect on BSP excretion into bile. Although conjugation does not appear to affect hepatic uptake of BSP directly, conjugation does appear to affect the maximal rate at which BSP is transported from liver cells into bile, conjugated BSP being transported more rapidly into bile.

\section{Acknowledgments}

The author is indebted to Mrs. Ruthie Lee Rose, Mr. George Molden, and Mrs. Mary Holcomb for invaluable technical assistance.

\section{References}

1. Combes, B., and G. S. Stakelum. Conjugation of sulfobromophthalein sodium with glutathione in thioether linkage by the rat. J. clin. Invest. 1960, 39, 1214.

2. Javitt, N. B., H. O. Wheeler, K. J. Baker, O. L. Ramos, and S. E. Bradley. The intrahepatic conjugation of sulfobromophthalein and glutathione in the dog. J. clin. Invest. 1960, 39, 1570.

3. Grodsky, G. M., J. V. Carbone, and R. Fanska. Biosynthesis of a sulfobromophthalein mercaptide with glutathione. Proc. Soc. exp. Biol. (N. Y.) 1961, 106, 526.

4. Combes, B., and G. S. Stakelum. A liver enzyme that conjugates sulfobromophthalein sodium with glutathione. J. clin. Invest. 1961, 40, 981.

5. Meltzer, J. I., H. O. Wheeler, and W. I. Cranston. Metabolism of sulfobromophthalein sodium (BSP) in dog and man. Proc. Soc. exp. Biol. (N. Y.) 1959, 100, 174.

6. Combes, B. The biliary excretion of sulfobromophthalein sodium (BSP) in the rat as a conjugate of glycine and glutamic acid. J. clin. Invest. 1959, 38, 1426.

7. Monroe, L. S., and A. L. Kittinger. The biliary dynamics of the metabolites of sulfobromophthalein sodium (BSP) in man. J. Lab. clin. Med. 1961, 58, 468.

8. Krebs, J. S., and R. W. Brauer. Metabolism of sulfobromophthalein sodium (BSP) in the rat. Amer. J. Physiol. 1958, 194, 37.

9. Philp, J. R., G. M. Grodsky, and J. V. Carbone. Mercaptide conjugation in the uptake and secretion of sulfobromophthalein. Amer. J. Physiol. 1961, 200, 545. 
10. Leaf, G., and A. Neuberger. The effect of diet on the glutathione content of the liver. Biochem. J. 1947, 41, 280.

11. Edwards, S., and W. W. Westerfield. Blood and liver glutathione during protein deprivation. Proc. Soc. exp. Biol. (N. Y.) 1952, 79, 57.

12. Combes, B., and G. S. Stakelum. Maturation of the sulfobromophthalein sodium-glutathione conjugating system in rat liver. J. clin. Invest. 1962, 41, 750 .

13. Grunert, R. R., and P. H. Phillips. A modification of the nitroprusside method of analysis for glutathione. Arch. Biochem. 1951, 30, 217.

14. Woodward, G. E. Glyoxalase. III. Glyoxalase as a reagent for the quantitative microestimation of glutathione. J. biol. Chem. 1935, 109, 1.

15. Gaebler, O. H. Determination of bromsulphalein in normal, turbid, hemolyzed or icteric serums. Amer. J. clin. Path. 1945, 15, 452.

16. Schenker, S., J. Goldstein, and B. Combes. Sulfo- bromophthalein sodium (BSP) conjugation and excretion in fetal guinea pigs. Amer. J. Physiol. 1965, 208, 563.

17. Bradley, S. E. The circulation and the liver. Gastroenterology 1963, 44, 403.

18. Mizuta, M., and B. Combes. Unpublished observations.

19. Wheeler, H. O., J. I. Meltzer, and S. E. Bradley. Biliary transport and hepatic storage of sulfobromophthalein sodium in the unanesthetized dog, in normal man, and in patients with hepatic disease. J. clin. Invest. 1960, 39, 1131.

20. Berke, R., and B. Combes. The effect of dietary protein on hepatic BSP removal mechanisms (abstract). Clin. Res. 1965, 13, 63.

21. Munro, H. N. General aspects of the regulation of protein metabolism by diet and by hormones in Mammalian Protein Metabolism, H. N. Munro and J. B. Allison, Eds. New York, Academic Press, 1964, vol. 1, p. 406. 